\title{
Investigation of the Amino Acid Composition of Tablets on the basis of Cryolophilized Xenoderm of Pigs
}

\author{
Ravliv Yu A ${ }^{1 \star}$, Pokotylo OO ${ }^{1}$, Pliushch VM$^{2}$ and Groshovyi TA ${ }^{1}$ \\ ${ }^{\prime}$ SHEI "Ternopil State Medical University of the MH of Ukraine, Ukraine \\ ${ }^{2}$ Volodymyr Vynnychenko Central Ukrainian State Pedagogical University, Ukraine
}

\section{Article Info}

\section{*Corresponding author: \\ Ravliv Yu A}

Department of Pharmacology

SHEI "Ternopil State Medical University of the $\mathrm{MH}$ of Ukraine

Samchuka 33/ str, Ternopil,

Ukraine index 46000

Ukraine

Tel: +38 0977205632

Email: ravlivuylia@ukr.net

\section{Received: May 25, 2018 \\ Accepted: July 10, 2018 \\ Published: July 16, 2018}

Citation: Ravliv YA, Pokotylo OO, Pliushch VM, Groshovyi TA. Investigation of the Amino Acid Composition of Tablets on the basis of Cryolophilized Xenoderm of Pigs. Madridge J Nov Drug Res. 2018; 2(1): 57-60. doi: $10.18689 / \mathrm{mjndr}-1000108$

Copyright: (c) 2018 The Author(s). This work is licensed under a Creative Commons Attribution 4.0 International License, which permits unrestricted use, distribution, and reproduction in any medium, provided the original work is properly cited.

Published by Madridge Publishers

\begin{abstract}
The problem of creating highly effective drugs based on natural raw materials, especially of animal origin, is becoming increasingly relevant. Simultaneously with the search for effective ways to optimize the processes of reparative tissue regeneration, the issue of development of medicines based on animal raw materials with the possibility of correcting adverse for the organism of destructive immunopathological processes remains an important issue. The source of structural proteins with a wide range of biological activity is inherent in a bioorganic substrate based on the skin tissue of xenogeneic origin. The purpose of our work was to investigate the amino acid composition of the developed tablets based on the cryolophilized xenoderm pigs. Materials and Methods: Quantitative determination was carried out by ion exchange liquid chromatography. For qualitative and quantitative analysis of amino acids, the method of ion exchange liquid-column chromatography (the principle of action is based on the acid-alkaline properties of these compounds) and the automatic analyzer $339 \mathrm{M}$ of the firm "Microtechna" (Czech Republic) Conclusion: The analysis of pills based on cryolophilized xenoderm of pigs with lecithin on the content of amino acids in the investigated objects was performed. As a result of the research, 19 amino acids were identified, 12 of which are irreplaceable.
\end{abstract}

Keywords: Amino acids; Cryolophilized xenoderm of pigs; Ion exchange liquid-column chromatography; Lecithin.

\section{Introduction}

The development of herbal medicines nowadays becomes very relevant. Along with the development of herbal medicines, there is a need to develop new drugs based on raw material of animal origin. So, a group of Ukrainian scientists under the leadership of prof. V.V. Bihuniak (LLC "Institute of Biomedical Technologies", Ternopil) has developed a dietary supplement "Xenoderm", which contains natural complexes of peptides, amino acids, micro-and macro elements, nucleotides, growth factors, etc. Such dietary supplement cause a wide range of pharmacological activity, accordingly: antihistamines, antiallergic, membrane-protector, anti-toxic and antimicrobial effects in allergic diseases; stimulate the effective healing of wounds and ulcers; improves the functioning of the digestive system; has the properties of a natural adsorbent.

\section{Material and Methods}

The purpose of this study was to study the amino acid composition of tablets based on the cryolophilized xenoderm of pigs and tablets based on the cryolophilized xenoderm of pigs with lecithin. The results of the study of drug samples fit into acceptable standards and show a high content of amino acids in the samples under study. Quantitative determination was carried out by ion exchange liquid chromatography. 


\section{Results}

As a result of the research, 19 amino acids were identified in the test material, including 12 indispensable. The results of the research of the amino acid composition of the powder and the tablets on the basis of cryoliophilized xenoderm of pig, pills based on the basis of cryoliophilized xenoderm of pig with lecithin are presented, as well as a comparison with respect to their quantitative content have been made. The result of the research was identification of the 19 amino acids, 12 amino acids from them turned out to be irreplaceable.

\section{Conclusion}

This analysis allowed the choice of a quality criterion for tablets based on cryolithophilized xenoderm pigs content of amino acids not less than $50 \mathrm{mg} / 1 \mathrm{~g}$ of the substance in terms of glycine.

Keywords: Amino acids; Cryolophilized xenoderm of pigs; lon exchange liquid-column chromatography; Lecithin.

\section{Introduction}

Proteins are complex organic compounds which are necessary for the construction of cells that perform hundreds of various functions in the human body, in particular, they participate in the reproduction of cells, in the formation of enzymes, in the production of antibodies and hormones. Proteins begin to collapse and to become the source of energy if there is a lack of energy in the human body. So a complete life is simply impossible without foods which contain proteins $[1,2]$.

The World Health Organization has identified health as a state of complete physical, mental and social well-being, and not merely the absence of disease or infirmity [3]. Good nutrition is an important criterion for maintaining of a person's physical health. That is why a balanced number of nutrients ensure the optimal functioning of the organism as an integral system. The quality of food can affect on the human psychics (for example, insufficiency of vitamins, endogenous amines and amino acids are the cause of many psychiatric disorders) [4].

A person need to get about 70 different ingredients with food and water every day, many of which are not synthesized in the body and therefore are vital for normal development of the organism and its activity. There is no ideal protein in the nature that contains all essential, unsubstitute and substitute amino acids in an optimal ratio. Animal proteins which are contained in the meat, fish, poultry, eggs and dairy products are considered to be complete due to the fact that the content of essential, unsubstitute amino acids in them is the same or even greater than in the ideal protein. Vegetable proteins are mostly inferior because they contain some essential, unsubstitute amino acids in a much smaller amount than the ideal protein. A person uses a protein mix in everyday life, which includes animal and vegetable proteins usually. This mixture is not ideal and it is assumed that its biological value is $70 \%$, if $100 \%$ accept as the biological value of the ideal protein. The human body is composed of almost $20 \%$ of proteins [5]. Amino acids are substances of the primary metabolism, whose main purpose is to participate in the synthesis of the protein. In addition, various amino acids are the initial materials that supply the nitrogen atom and fragments of the carbon chain to form a large number of physiologically active compounds [5].

Among the biostimulators of the animal origin are the following drugs: vitreous body, placenta curl for injections; extract of placenta for injection; amniocene, amniocene for injections; honsuryde; rumalone; plasmol, splenin; solcoseril; actovegin; apilac; propolis; preparation in aerosol "Proposol"; ointment "Propoceum", tincture of propolis; flower pollen [6].

The effect of homology is the pharmacological effect on homologous organs or tissues is an important feature of preparations made from organs, which significantly distinguishes them from other means. It means that the pharmacological effect after use age of preparations made from organs is manifested precisely in those organs and tissues from which the drug was obtained. Preparations made from organs replenish the deficiency of the cellular biomolecules, eliminate various "cellular defects" at the cellular level, and improve the processes of physiological regeneration in the respective organs of the patient due to the effect of organotropy. This leads to a normal renovation of organs and tissues, to the restoration of their lost functions, preparations made from organs rejuvenate the cells as well, increase the resistance of cells to hypoxia, to the effects from toxins activity and other damaging factors, they also positively affect on the metabolism in them, increase the efficiency of tissues to absorption of nutrients and to the elimination of metabolism products, besides that preparations optimize the processes of recovery of the organ and tissue [7].

Technologies of the production of a granulated substrate of cryoliophilized xenoderm of pig have developed in the "Institute of Biomedical Technologies" Ltd [8].

\section{Objectives}

The purpose of this work was to research and conduct a comparative assessment of the amino acid composition of tablets on the basis of cryoliophilized xenoderm of pig, tablets on the basis of cryoliophilized xenoderm of pig with lecithin and powder.

\section{Materials and Methods of the Research}

Powder, pills on the basis of cryoliophilized xenoderm of pig, pills on the basis of cryoliophilized xenoderm of pig with lecithin were selected as a research objects. Quantitative determination was carried out by ion exchange liquid chromatography. Ionic chromatography has developed and matured as an important analytical methodology in a number of spheres, industry, including pharmaceuticals production [9].

The method of ion exchange liquid-geyser chromatography (the principle of action of this method is based on the acidalkaline properties of these compounds) and the automatic analyzer $339 \mathrm{M}$ of the Microtechna firm (Czech Republic) (functioning of the analyzer based on the principle of conducting analysis in a continuous flow of eluent: the eluent 
from the tank is passed through a chromatographic geyser while a metering pump is used) have been used for qualitative and quantitative analysis of amino acids. The ninhydrin reagent is continuously fed to the eluate at the exit of the geyser, in a certain ratio with the eluant. The mixture of eluate and ninhydrin reagent sents to the reactor which heated to a temperature of $95-98^{\circ} \mathrm{C}$ then, and after that goes to a flow cuvette. The intensity of the formed color is measured by the photocell, which lighted by the source of the light which enters through the walls of cuvette. The signals of the photocell are amplified and then recorded by a recording device in the form of a chromatogram.

A standard mixture of amino acids with a known concentration of each pre-applies on the geyser of analyzer to calculate the amount of amino acids in the samples. The area (or height) of the peak for each amino acid determines on the chromatogram. The amount of micromoles of each amino acid (X1) in the researched preparations is calculated according to the next formula: $\mathrm{X} 1=\mathrm{S} 1$ / S0, where S1 is the area (or height) of the peak of the amino acid in the sample which is under the test; $\mathrm{S} 0$ is the area (or height) of the peak of the same amino acid in a solution of a standard mixture of amino acids corresponding to 1 micromol of each amino acid. The amount of amino acids in milligrams is obtained by multiplying of the amount of micromoles of an amino acid to its corresponding molecular weight. The qualitative composition of the amino acid mixture is determined by comparing the standard chromatogram with the chromatogram of the mixture which is under the test $[10,11]$.

\section{Results}

Our previous researches were concerned on the researching of the amino acid composition of tablets on the basis of cryoliophilized xenoderm of pig [12]. The leading in of lecithin into a tablet mass had led to the creation of tablets on the basis of the cryoliophilized xenoderm of pig with lecithin, which was tested at first to find out the content of amino acid. 19 amino acids were identified in the test material, including 12 unsubstitutable ones.

Composition of amino acids in 3 researched objects is given in the table No1.

Table No: Content of amino acids in powder, in tablets on the basis of cryoliophilized xenoderm of pig, in pills on the basis of cryoliophilized xenoderm of pig with lecithin

\begin{tabular}{|c|c|c|c|c|c|c|c|}
\hline Amino acids & $\begin{array}{l}\text { Amount } \\
\text { (in } 100 \\
\text { mg) in } \\
\text { pills on } \\
\text { the basis } \\
\text { of cryolio- } \\
\text { philized } \\
\text { xenoderm } \\
\text { of pig }\end{array}$ & $\%$ & $\begin{array}{l}\text { Amount } \\
\text { (in } 100 \\
\text { mg) in } \\
\text { pills on } \\
\text { the basis } \\
\text { of cryolio- } \\
\text { philized } \\
\text { xenoderm } \\
\text { of pig with } \\
\text { lecithin }\end{array}$ & $\%$ & $\begin{array}{l}\text { Amount } \\
\text { (in } 100 \\
\text { mg) in the } \\
\text { powder of } \\
\text { the cryo- } \\
\text { liophilized } \\
\text { xenoderm } \\
\text { of pig }\end{array}$ & $\%$ & $\begin{array}{l}\text { Substitutable / } \\
\text { Unsubstitutable } \\
\text { Amino Acids }\end{array}$ \\
\hline O-Lizyn & 0,127 & 0,41 & 0,105 & 0,35 & 0,358 & 0,41 & Unsubstitutable \\
\hline Lizyn & 1,499 & 4,89 & 1,416 & 4,80 & 4,517 & 5,15 & Unsubstitutable \\
\hline Histydyn & 0,414 & 1,35 & 0,315 & 1,07 & 1,121 & 1,28 & Unsubstitutable \\
\hline Arhinyn & 2,219 & 7,24 & 1,960 & 6,64 & 6,718 & 7,66 & Unsubstitutable \\
\hline
\end{tabular}

\begin{tabular}{|l|l|l|l|l|l|l|l|}
\hline O-prolin & 1,638 & 5,35 & 1,686 & 5,71 & 2,594 & 2,96 & Substitutable \\
\hline $\begin{array}{l}\text { Asparahinic } \\
\text { Acid }\end{array}$ & 2,114 & 6,90 & 2,080 & 7,05 & 5,161 & 5,89 & Substitutable \\
\hline Treonin & 0,930 & 3,04 & 0,848 & 2,87 & 2,823 & 3,22 & Unsubstitutable \\
\hline Seryn & 1,941 & 6,34 & 1,936 & 6,56 & 5,983 & 6,82 & Substitutable \\
\hline $\begin{array}{l}\text { Hlutaminic } \\
\text { Acid }\end{array}$ & 4,566 & 14,91 & 4,031 & 13,66 & 12,569 & 14,33 & Substitutable \\
\hline Prolyn & 2,054 & 6,70 & 1,652 & 5,60 & 6,607 & 7,54 & Substitutable \\
\hline Glycine & 5,153 & 16,82 & 5,872 & 19,90 & 14,737 & 16,81 & Unsubstitutable \\
\hline Alaninium & 2,225 & 7,26 & 2,336 & 7,92 & 6,724 & 7,67 & Substitutable \\
\hline Cysteinium & 0,360 & 1,18 & 0,290 & 0,98 & 1,901 & 2,17 & Substitutable \\
\hline Valinium & 0,804 & 2,63 & 0,863 & 2,92 & 1,931 & 2,20 & Unsubstitutable \\
\hline Metioninium & 0,412 & 1,35 & 0,295 & 1,00 & 1,209 & 1,38 & Unsubstitutable \\
\hline Isoleytsinium & 0,647 & 2,11 & 0,613 & 2,08 & 2,111 & 2,41 & Unsubstitutable \\
\hline Leycinium & 1,838 & 6,00 & 1,581 & 5,36 & 5,188 & 5,92 & Unsubstitutable \\
\hline Tyrosinium & 0,747 & 2,44 & 0,715 & 2,42 & 2,480 & 2,83 & Unsubstitutable \\
\hline Fenilalaninum & 0,943 & 3,08 & 0,918 & 3,11 & 2,954 & 3,37 & Unsubstitutable \\
\hline Total: & 30,630 & 100,00 & 29,509 & 100,00 & 87,684 & 100,00 & \\
\hline
\end{tabular}

Glycine was selected as the quality marker in the developed tablets because taking into account the obtained results of the amino acid composition of the tablets on the basis of the cryoliophilized xenoderm of pig with lecithin [12].

This analysis allowed to choose content of amino acids not less than $50 \mathrm{mg} / 1 \mathrm{~g}$ of the substance in terms of glycine as a quality criterion for the tablets on the basis of cryoliophilized xenoderm of pig. Glycine, which is most commonly found in pillson the basis of cryoliophilized xeroderm of pig with lecithin, can be used to reduce symptoms in persons who suffer from such phenomena as ulceration, arthritis, diabetes, renal and heart failure, neuro-behavioral disorders, chronic fatigue, sleep disorders, and even some types of cancer. It has been found that glycine helps to inhibit the deterioration of valuable protein tissues that create muscles and improves recovery of the muscles. In fact, this amino acid (glycine) is characterized by the so-called "anti aging" effect because it helps to maintain a soft muscle mass in older age, stimulates the secretion of the human growth hormone, prevents loss of cartilage in the joints, and even improves daily energy, physical efficiency and mental faculties. Glycine is used during the biosynthesis of creatine, which provides muscles with a direct source of fuel for the repairing of the damages. It also has the benefits in producing of hormones and in regulating of them, helping the human organism to synthesize naturally steroid hormones that regulate the ratio of fat to muscle mass and to control the energy expenditure. This amino acid plays an important role in the formation of collagen, contributing to the growth and functioning of joints, tendons and ligaments. About one third of the collagen consists of glycine, and collagen is a crucial for the formation of connective tissue that supports flexibility of joints. It is especially important to consume sufficient amount of proteins (amino acids) when people get older, to repair damaged tissues inside the joints that suffer from the damage caused by free radicals. Glycine is important for the formation of tensile, flexible cartilage, helps in strengthening of the damaged joints, and in preventing loss of mobility and functionality of them in the elderly. This amino acid helps persons who are suffering from the food allergy and sensitivity, 
to digest food easily, and can soothe the lining of the gastrointestinal tract in persons with inflammatory bowel disease or stomach upset also.

Glycine also acts as a metabolic fuel within the GI tract. There is a need to produce bile, nucleic acids, creatine phosphate and porphyrins that are used in the splitting of the nutrients from your diet. Glycine helps break down fats by promoting the production of bile acids and helps to transport glycogen into the cells that will be used for energy in the form of ATP for example. Evidences also show that the glycine can help to stabilize sugar level in blood, resulting for longer energy and prevents cravings and tiredness of sugar.

Glycine helps to form glutathione, a valuable antioxidant that is used to prevent cell damage and various signs of aging. Glycine helps to prevent cellular mutations that lead to cancer have even found in some researches. There are some evidences which show that using of the targeted amino acid therapy can prevent the growth of cancer cells by cutting off their energy supply and also helping to prevent inflammation that is associated with numerous other chronic diseases, with the exception of cancer.

Glycine is useful for supporting of cognitive functions and the central nervous system, as it helps to regulate the metabolic synthesis of certain nutrients that used by brain and nerves for energy. It helps to regulate nerve impulses throughout the human organism by balancing of levels of such electrolytes as calcium, chloride and potassium [13].

The obtained results in the researching of the immunotropic properties of the powder from the cryoliophilized xenoderm of pig and the theoretical background substantiate the feasibility and perspectivity of the further research of the mechanisms of action of the xenoderm for the purpose of creation a highly effective antiallergic agent for the pathogenetic therapy of the allergic dermatitis [14].

Significant antihistamines, anti-inflammatory, antiallergic properties and membrane-protective effects of the action of the xenoderm of pig were established as a result of conducted research under the direction of Pyatnitsky Y.S. [15].

\section{Conclusion}

The analysis of pills on the basis of cryoliophilized xenoderm of pig with lecithin which was aimed at detecting of the content of amino acids in the tested objects was performed. This analysis allowed to choose content of amino acids not less than $50 \mathrm{mg} / 1 \mathrm{~g}$ of the substance in terms of glycine as a quality criterion for the tablets on the basis of cryoliophilized xenoderm of pig. 19 amino acids were identified, including 12 unsubstitutable ones. The results of this research indicate a high composition of amino acids, which can be used successfully as a promising factor for directed correction of the structures and functions of the body damaged by the pathologic processes during a variety of diseases. The content of glycine in a tablet with lecithin is greater in comparison to the tablet, which do not include lecithin from sunflower.
We have came to the conclusion while analyzed the obtained results on the content of the substitutable and unsubstitutable amino acids, that the use age of pills on the basis of the cryoliophilized xenoderm of pig, pills on the basis of the cryoliophilized xenoderm of pig with lecithin is perspective as well as further pharmaceutical developments for obtaining of a complex preparations made from organs is also feasible.

\section{References}

1. Gryshyna EO. Proteins and their role in the organism. Scientific notes of KNTU. 2011; 1: 237.

2. Joint FAO / WHO / UNU Expert Consultation on Protein and Amino Acid Requirements in Human Nutrition (2002; Geneva, Switzerland)

3. Constitution (Constitution) of the World Health Organization // Basic Documents. - 40th edition. - Geneva; 1995: 5-26.

4. 4.1) Tyrkin DD. Balanced nutrition as an important resource of the human health. Gender Ecology. 2017; 20-21.

4.2) Pytetska NI. Health Materials of the $V$ International Scientific and Practical Conference Kharkiv. KhNMU-Kharkiv. 2017; 72-174.

5. Oleksiyenko OI, Shakhmatova VA, Vereshchagina OP, Cherkasy PE, Chabanenko YA. Nutrition and its Influence on the Human Health. Textbook. 2014; 42.

6. Dmytrievskyj DI, Bohuslavska LI, Khokhlova L.M. The technology of medicinal products of industrial production, Teaching methods. Vinnytsa: The New Book. 2008; 280.

7. Institute of biomedical technologies.

8. Hroshovy TA, Trugubchak OV, Ravliv YA, Kalushka OB. Research and establishment of tablets based on cryoliophilized xenoderm of pigs with lecithin by direct extrusion, International scientific congress "Modern directions in chemistry, biology, pharmacy and biotechnology". Lviv. 2015; 29-2: 37-38.

9. Dennis Jenke lon Chromatography in Pharmaceutical and Drug Analysis Journal of Chromatographic Science. 2011; 49: 524-539.

10. Sorochan O, Shtemenko NI. Methods for Analyzing of Amino Acids. Teaching Method. 2005; 60.

11. Andreeva OA, Tegza MM. Determination of the Amino Acid Content of Collagen Preparations Obtained from Leather Waste Products. KNUTD Newsletter. 2011; 2: 121-126.

12. Ravliv YA, Groshovoi T A, Tsymbalyuk AV. Research of the amino acid composition of the pills on the basis of the cryoliophilized xenoderm of the pig [Electronic resource]. Medicines of Ukraine plus. 2014; 2(19): 67-69.

13. Glycine: The Muscle-Building, Brain-Boosting Amino Acid that Benefits the Entire Body. Jillian Levy. 2016.

14. Pyatnytskyj YS, Yakovleva LV, Koshova OY. Influence of substrate of cryopreserved pig's skin on immune response of rats with normal homeostasis. Clinical pharmacy. 2014; 18(2): 34-40.

15. Pyatnytskyj YS, Yakovleva LV, Koshova OY. Experimental study of pharmacological properties of cryopreserved skin substrate of pigs. Clinical pharmacy. 2013; 17(1): 56-63. 